\title{
KAJIAN KRITIS TERHADAP HUKUM PERDATA (KUHPERDATA) DALAM ASPEK FILOSOFIS
}

\author{
Anwar Hidayat
}

\author{
Universitas Buana Perjuangan Karawang
}

Email: anwar.hidayat@ubpkarawang.ac.id

\begin{abstract}
Abstrak
Hukum merupakan suatu sistem terpenting di dalam masyarakat untuk mengatur kehidupan yang berkaitan dengan sebuat tatanan yang selalu bergerak baik secara evolutif maupun revolusioner. Tatanan diatur dalam hukum itu sendiri meliputi tatanan transendetal, tatanan sosial/masyarakat dan tatanan politik. Hukum perdata yang merupakan ketentuan atau peraturan yang berkaitan dengan pribadi seseorang dengan orang lain, atau juga hukum sipil memiliki ruang lingkup yang luas dalam pengaturannya. Salah satu bidang hukum yang mengatur hubungan-hubungan antara individu-individu dalam masayrakat dengan sarana tertentu. Penggolongan dari hukum perdata yang ada saat ini antara lain meliputi: Hukum keluarga, Hukum harta kekayaan, Hukum kebendaan, Hukum perikatan, dan Hukum waris. Kajian kritis terhadap hukum perdata yang telah berlaku di Indonesia dengan menggunakan metode filsafat (filosofis), maka seharusya yang dijadikan dasar pemikirannya ialah falsafah Pancasila. Sebagaimana diketahui bahwa Pancasila merupakan sumber dari segala sumber hukum negara Indonesia. Hal yang demikian ini dirasa sesuai mengingat falsafah Pancasila adalah merupakan ruh perjuangan dari para pejuang bangsa, sebagai alat pemersatu, dari yang sebelumnya terkotak-kotak oleh suatu daerah/wilayah, ras, suku, golongan dan agama.
\end{abstract}

Kata Kunci: Hukum Perdata, Filosofis, Pancasila

Abstract
The law is the most important system in society to regulate life in relation to an order that is always
moving both evolutionarily and revolutionarily. Order is regulated in the law itself including
transcendental order, social/community order and political order. Private law which is a provision
or regulation relating to someone's personal with others, or also civil law has a broad scope in its
regulation. One area of law that regulates the relationships between individuals in society with
certain means. The current classification of private law includes: Family law, Property law, Material
law, Engagement law, and inheritance law. Critical study of private law that has prevailed in
Indonesia using philoshopy (philosophical) methods, then the basis for thinking should be the
philosophy of Pancasila. As is known that Pancasila is the source of all sources of Indonesian state
law. This is considered appropriate given the philosophy of Pancasila is the spirit of the struggle of
the nation's fighters, as a unifying tool, from previously divided by a region / region, race, ethnicity,
class and religion.

Keyword: Private Law, Philosophical, Pancasila. 


\section{PENDAHULUAN}

Hukum merupakan suatu sistem terpenting di dalam masyarakat untuk mengatur kehidupan yang berkaitan dengan sebuat tatanan yang selalu bergerak baik secara evolutif maupun revolusioner. Tatanan dalam diatur dalam hukum itu sendiri meliputi tatanan transendetal, tatanan sosial/masyarakat dan tatanan politik. Sehingga dikatakan juga bahwa hukum merupakan sistem pengatur dalam segala aspek kehidupan manusia. Tujuan adanya hukum dijadikan sebagai sarana untuk patokan perilaku manusia dalam menentukan setiap perbuatan yang dilakukan adalah berdampak baik maupun buruk.

Para filsuf memberikan pemahamannya mengenai hukum tersebut misalnya Von Savigny menyatakan bahwa hukum merupakan pengejawantahan atau penerapan kesadaran hukum masyarakat. Dalam ajaran ini menemukan pembenaran bahwa hukum berbeda-beda antara masyarakat yang beraneka ragam pula. Perkembangan hukum tidak terlepas dari adanya politik dan kekuasaan dari suatu wilayah. Hukum dan manusia mempunyai hubungan yang khas dan tidak dapat dipisahkan. Hukum ada untuk memberikan aturan bagi manusia yang menerapkan hukukm tersebut, tanpa adanya manusia maka hukum tersebut tidak ada fungsinya bagi kehidupan.

Pemakaian Hukum Perdata awalnya disampaikan oleh Djojodiguno sebagai Burgerlijkrecht di saat masa penjajahan oleh Bangsa Jepang. Hukum perdata merupakan hukum sipil dan hukum privat. Sifat tersebut yang khas dalam Hukum Perdata sehingga pengaturan di dalam hukum tersebut sangat bersinggungan langsung dengan subyek hukum itu sendiri. Menurut Prof Subekti bahwa hukum perdata mengandung beberapa istilah di antaranya, pertama: hukum perdata dalam arti luas meliputi semua hukum materiil yaitu segala hukum pokok yang mengatur kepentingan-kepentingan perseorangan. Termasuk dalam pengertian hukum perdata dalam arti yang luas ini adalah hukum dagang. Kedua: hukum perdata dalam arti yang sempit, dipakai sebagai lawan dari hukum dagang. ${ }^{1}$

\footnotetext{
${ }^{1}$ Tutik Titik Triwulan, Hukum Perdata dalam Sistem Hukum Nasional, Kencana, Jakarta, 2010, hlm. 28.
} 
Dalam sejarah singkatnya mengenai hukum perdata Belanda berasal dari hukum perdata Perancis yaitu disusun berdasarkan hukum Romawi "Corpus Juris Civils" yang pada waktu itu diangap sebagai hukum yang paling sempurna. Hukum perdata sebagai hukum privat yang berlaku di Perancis dimuat dalam dua kodifkasi yang disebut Hukum perdata dan hukum dagang (code de commerce). ${ }^{2}$ Oleh sebab itu, hukum perdata selama ini yang masih berlaku bagi Bangsa Indonesia masih sangat kental pengaturannya pada setiap-setiap tindakan manusia di wilayah Indonesia sebagai negara bekas jajahan bangsa Belanda.

Hukum perdata Indonesia itu sendiri adalah hukum perdata yang berlaku bagi seluruh wilayah di Indonesia. Hukum perdata yang berlaku di Indonesia adalah hukum perdata barat (Belanda) yang pada awalnya berinduk pada Kitab Undang-Undang Hukum Perdata (KUHPdt) yang dalam bentuk aslinya menggunakan bahasa Belanda, dan dikenal sebagai Burgerlijk Wetboek (BW). Selanjutnya di

\footnotetext{
${ }^{2}$ Anonim, dalam website: https://id.scribd.com/doc/91476706/SejarahHukum-Perdata-Indonesia
}

Indonesia, sebagaina materi di dalam BW tersebut sudah dicabut berlakunya dan telah diganti dengan UndangUndang Republik Indonesiia misalnya tentang Perkawinan, hipotik, Kepailitan, Agraria dan lain sebagainya.

\section{PERMASALAHAN}

Berdasarkan hal-hal yang telah diungkapkan dalam latar belakang, maka dibuatlah rumusan masalah dalam tulisan ini yaitu bagaimana kajian aspek filosofis terhadap regulasi pada hukum perdata/Kitab Undang-Undang Hukum Perdata di Indonesia?

\section{METODE PENELITIAN}

Metode pendekatan yang digunakan dalam penulisan ini adalah dengan yuridis-normatif. Pendekatan tersebut dimaksudkan jenis penelitian dogmatis dan bentuk penelitian perskriptif dalam hubungan pada hukum-hukum. Selanjutnya spesifikasi penelitian ini yaitu deskriptif analitis, yakni dengan memberikan gambaran terhadap masalah yang diangkat dan memberikan analisis dari masalah sehingga mampu memberikan jawaban atas permasalahan tersebut.

Metode pengumpulan data dalam penelitian ini adalah menggunakan 
metode kepustakaan (library research) dengan maksud menguji bahan-bahan dokumen dan bahan pustaka yang digunakan dalam penelitian ini. Data dianalisis secara kualitatif normatif, yaitu melakukan penelitian dengan jalan menafsirkan dan membangun pernyataan yang terdapat dalam dokumen peraturan perundangundangan. Metode analisis kualitatif, dibangun berdasarkan data dan substansinya yang berasal atau bersumber dari berbagai literatur seperti buku, jurnal, dan karya ilmiah, peraturan perundang-undangan, dan data primer yang diperoleh dari wawancara, pengamatan dan studi lapangan. Selanjutnya dari bahan-bahan tersebut akan dianalisis dengan normatifnya sebagaimana diatur dalam undang-undang, teori dan pendapatpendapat para ahli hukum.

\section{PEMBAHASAN}

Kajian Aspek Filosofis Terhadap Regulasi Pada Hukum Perdata/Kitab Undang-Undang Hukum Perdata Di Indonesia

\section{Perkembangan Hukum Perdata/ \\ KUHPerdata di Indonesia}

Hukum yang berkembang di dalam masyarakat memberikan tujuan untuk menciptakan keteraturan dan ketertiban bagi kelompok masyarakat itu sendiri.Pelaksanaan hukum seharusnya dapat berjalan dengan damai, secara normal namun juga terdapat pelanggaran yang dilakukan oleh tiap masyarakat itu sendiri. Dalam penerapan hukum pasti berkaitan dengan adanya peristiwa/kejadian yang dialami oleh subyek hukum tersebut. Setiap orang mengharapkan dapat ditetapkannya hukum dalam hal terjadi peristiwa yang nyata (konkret).

Hukum perdata yang merupakan ketentuan atau peraturan yang berkaitan dengan pribadi seseorang dengan orang lain, atau juga hukum sipil memiliki ruang lingkup yang luas dalam pengaturannya. Salah satu bidang hukum yang mengatur hubunganhubungan antara individu-individu dalam masayrakat dengan sarana tertentu. Penggolongan dari hukum perdata yang ada saat ini antara lain meliputi:

a. Hukum keluarga; 
b. Hukum harta kekayaan;

c. Hukum kebendaan;

d. Hukum perikatan;

e. Hukum waris

Dari ruang lingkup di atas, maka hukum perdata memiliki lingkup yang luas pengaturannya dan hanya sebatas pada diri subyek hukum tersebut. Sistem hukum perdata yang berlaku di Indonesia bersifat plurasim (beraneka ragam). Keanekaragaman ini sudah berlangsung sejak masa penjajahan Belanda. Konsekuensi dengan adanya keanekaragama pemberlakuan hukum perdata ini maka, ada sebagian aturan yang sifatnya khusus bagi kelompok orang itu sendiri. Adapun golongangolongan penduduk di Indonesia yang didasarkan pada pemberlakuan hukum perdata antara lain golongan eropa, golongan timur asing, dan golongan bumi putera (pribumi). ${ }^{3}$

Sejarah dalam pemberlakuan hukum perdata Indonesia yang selama ini masih digunakan merupakan proses yang panjang dan bertahap serta terus menerus. Proses ini mengalami dan megandung kebenaran keilmuan yang merupakan hasil berfikir hakiki berupa

\footnotetext{
${ }^{3}$ Pasal 163 Indishce Staatblad (IS)
}

generalisasi yang maknanya bersifat umum sementara implementasi dan operasionalnya dalam empiris berbeda. Pada tanggal 31 Oktober 1837 oleh C.J Scholten diangkat sebagai Ketua panitia kodifikasi dengan A.A van Vloten dan Meyer, dimana mereka masing-masing sebagai anggota, yang kemudian anggotanya tersebut diganti dengan J. Scheneither dan A.J Van Nes. Di Indonesia telah diumumkan bahwa pada tanggal $30 \quad$ April 1847 melalui Staatsblad No. 23 dan berlaku Januari 1848 dengan berlakunya asas konkordasi (asas persamaan), dimana setelah Indonesa merdeka maka ketentuan pada Pasal 2 aturan peralihan UUD Republik Indonesia menyatakan:

"Segala badan negara dan peraturan yang masih ada masih langsung berlaku, selama belum diadakan yang baru menurut UndangUndang Dasar ini”.

Kitab Undang-Undang Hukum Perdata (KUHPerdata) Hindia Belanda berlaku sebelum digantikan dengan Undang-Undang baru berdasarkan Undang-Undang dasar ini. Burgerlijk Wetboek (BW) Hindia Belanda disebut juga sebagai Kitab Undang-Undang Hukum Perdata Indonesia sebagai buku induk hukum perdata. Menurut Sudikno 
Mertokusumo bahwa keberlakuan hukum pada produk dan peninggalan Belanda tersebut di Indonesia didasarkan pada beberpa peninggalan antara lain: ${ }^{4}$

1) Para ahli tidak pernah mempersoalkan secara mendalam tentang mengapa hukum Belanda masih berlaku di Indonesia. Tatanan hukum Indonesia hendaknya tidak dilihat sebagai kelanjutan dari tata hukum Belanda, tetapi sebagai hukum nasional.

2) Sepanjang hukum tersebut tidak bertentangan dengan Pancasila dan UUD 1945, peraturan perundang-undangan serta dibutuhkan; dan

3) Apabila hukum tersebut bertentangan, maka menjadi tidak berlaku lagi.

Kaidah hukum perdata dapat dilihat dari beberapa hal, antara lain bentuk, subyek hukum, dan substansinya. Berdasarkan bentuk hukum perdata dapat dibedakan menjadi dua macam, yaitu tertulis dan tidak tertulis. Kaidah hukum perdata tertulis, terdapat di

${ }^{4}$ Tutik, Op.Cit, hlm. 58 dalam peraturan peraturan-peraturan perundang-undangan, seperti KUHPerdata, Undang Undang Nomor 1 tahun 1974 tentang Perkawinan. Adapun kaidah hukum tidak tertulis adalah kaidah-kaidah hukum perdata yang timbul, tumbuh, dan berkembang dalam praktek kehidupan bermasyarakat (kebiasaan/adat) seperti hukum adat dan hukum Islam.

Dalam rangka kajian terhadap suatu produk hukum yang berlaku (hukum positif) jika didasarkan pada perkembangan masyarakat yang sangat dinamis, maka persoalan-persoalan atas ketentuan hukum positif (hukum perdata) akan semakin banyak. Oleh karenanya, perlu metode atau cara dalam memahami gambaran yang jelas mengenai persoalan dalam hukum itu sendiri. Penggunaan metode filsafat (kontemplasi) terhadap persoalan hukum mampu memberikan pemikiran yang lebih menyeluruh/utuh. Dilihat dari perkembangan aliran pemikiran (hukum) satu aliran pemikiran akan bergantung pada aliran pemikiran lainnya sebagai sandaran kritik untuk membengun kerangka teoritik berikutnya. Munculnya aliran pemikiran baru tidak otomatis bahwa aliran atau 
pemikran lama ditinggalkan. Sulitnya untuk meramu seluruh ide yang berkembang dalam hukum karena dua alasan yaitu:

Pertama, hukum adalah objek kajian yang masih harus dikonstruksi (dibangun) sebagaimana kaum konstrukvitis menjelaskan, diciptakan menurut istilah positivistic atau menggunakan bahasa kaum hermeniam 'ditafsirkan' sehingga dengan demikian cara pandang seseorang tentang hukum akan ditentukan oleh bagimana orang tersebut mengonstruksi, menciptakan atau menafsirkan mengenai apa yang disebut hukum itu.

Kedua, satu pemikiran (aliran tertentu) akan memiliki latar belakang atau sudut pandang yang berbeda dengan aliran (pemikiran) lain, ini merupakan ragam kelemahan dan keunggulan masing-masing. Kondisi ini pada dasarnya memberikan keleluasaan karena hukum akan menjadi wilayah terbuka yang mungkin saja hasilnya lebih positif.
2. Pemikiran Filsafat Terhadap

Keberadaan Hukum Perdata

Jika kita berbicara filsafat, kita seakan berada pada ranah yang sangat abstrak, dan filsafat hukum merupakan cabang dari filsafat, filsafat hukum mempunyai fungsi yang strategis dalam pembentukan hukum di Indonesia. Pengertian Filsafat dalam Kamus Besar Bahasa Indonesia, adalah pengetahuan dan penyelidikan dengan akal budi mengenai hakikat segala yang ada, sebab, asal, dan hukumnya, arti lainnya yakni suatu teori yang mendasari alam pikiran atau suatu kegiatan atau juga berarti ilmu yang berintikan logika, estetika, metafisika dan epistemologi.

Dalam konteksnya kajian kritis terhadap hukum perdata yang telah berlaku di Indonesia dengan menggunakan metode filsafat (filosofis), maka seharusya yang dijadikan dasar pemikirannya ialah falsafah Pancasila. Sebagaimana diketahui bahwa Pancasila merupakan sumber dari segala sumber hukum negara Indonesia. Hal yang demikian ini dirasa sesuai mengingat falsafah Pancasila adalah merupakan ruh perjuangan dari para pejuang bangsa, 
sebagai alat pemersatu, dari yang sebelumnya terkotak-kotak oleh suatu daerah/wilayah, ras, suku, golongan dan agama. Merupakan latar belakang dari masyarakat Indonesia yang heterogen dan majemuk, sehingga dengan didasarkan pada nilai-nilai Pancasila mampu menjunjung cita-cita luhur para pejuang untuk menciptakan masyarakat yang adil dan makmur sejahtera dapat diwujudkan bagi masyarakat Indonesia secara keseluruhan.

Kebenaran ilmu adalah hasil usaha manusia berpikir dan menyelidiki tentang pengetahuan dan keilmuan menghasilkan kebenaran nisbi, yang selalu dapat berubah dan berkembang. Ilmu berawal dari dorongan ingin tahu manusia yang sangat besar untuk tahu sesuatu yang menghasilkan pengetahuan (knowledge) yakni segala sesuatu yang diketahui manusia demi kesadaran manusiawinya. Manusia memiliki pengetahuan demi ingin tahunya yang tak terbatas, pengetahuan diterima manusia dengan atau tanpa menguji kebenarannya.

Pengetahuan diterima dan dimiliki manusia sepanjang dapat memuaskan dorongan ingin tahunya. Demikian juga dalam hukum perdata yang mana merupakan hasil berfikir manusia seiring dengan perkembangan zaman dan perubahan dalam berbagai hal. Banyak Undang-undang yang diubah atau dicabut karena tidak sesuai lagi.

Sebagaimana dikemukakan di atas, Sepanjang hukum tersebut tidak bertentangan dengan Pancasila dan UUD 1945, peraturan perundangundangan serta dibutuhkan dan apabila hukum tersebut bertentangan, maka menjadi tidak berlaku lagi. Disebut tidak berlaku bilamana terdapat Undang Undang yang bertentangan dapat diamandemenn oleh Anggota DPR dan dapat diajukan ke Mahkamah Konstitusi disebabkan Menurut Undang-Undang Dasar 1945, kewajiban dan wewenang MK adalah : berwenang mengadili pada tingkat pertama dan terakhir yang putusannya bersifat final untuk menguji Undang-Undang terhadap UndangUndang Dasar. Dalam legal awareness (kesadaran hukum), gatra kognitif merujuk pada pengetahuan seseorang tentang ada tidak aturan yang mengatur perbuatan yang sedang ia lakukan atau tengah menjadi perhatian utama, sedangkan gatra efektifnya merujuk ke pelibatan dirinya secara emosional ke suatu pihak tertentu, berdasarkan 
keyakinan bahwa apa yang ia ketahui itu merupakan sesuatu yang benar sehinga sudah seharusnya kalau ia turuti dan patuhi (atau merupakan ssuatu yang tidak benar, jadi sudah seharusnya dilawan). ${ }^{5}$

Dalam berfikir filsafat secara umum akan mengenalisis dengan menggunakan aspek landasan yang digunakan antara lain ontologis, epistemologis dan aksiologis. Berkaitan dengan kajian hukum perdata yang telah berlaku di Negara Indonesia sejauh ini perlu dipahami mengenai

Menurut istilah ontologi adalah ilmu yang membahas tentang hakikat yang ada, yang merupakan ultimate reality baik yang berbentuk jasmani/konkret maupun rohani/abstrak. ${ }^{6}$ Lain halnya Suriasumantri, bahwa ontologi adalah membahas tentang apa yang ingin kita ketahui, seberapa jauh kita ingin tahu, atau suatu pengkajian mengenai teori tentang "ada". Dalam hal hukum perdata secara ontologis merupakan norma/aturan yang berisi mengenai

${ }^{5}$ Hadi Sutoyo, Komitmen Hukum dan Kritik Legalisme bagi Hakim, Varia Peradilan No. 293, April 2010.

${ }^{6}$ Amsal Bakhtiar, Filsafat Ilmu, Raja Grafindo Persada, Jakarta, 2010, hlm. 35. hubungan hak dan kewajiban pada setiap diri manusia seperti perkawinan, harta benda, waris, dan lain sebagainya. Hukum perdata merupakan pedoman bagi subyek hukum sebagai pelaksana dari hak dan kewajiban sebagaimana ada pada diri manusia.

Epistemologi atau teori pengetahuan ialah cabang filsafat yang berurusan dengan hakekat dan lingkungan pengetahuan, pengandaianpengandaian dan dasar-dasarnya serta pertanggungjawaban atas pernyataan mengenai pengetahuan yang dimiliki. Epistemologi adalah pembahasan mengenai metode yang digunakan untuk mendapatkan pengetahuan. Dalam konteks hukum perdata merupakan peraturan yang mengatur hal-hal yang sangat esensial bagi kebebasan individu, hak milik dan perikatan. Epistemologi dalam hukum perdata berkaitan dengan adanya peristiwa-peristiwa hukum yang dialami oleh setiap individu yang diakomodir menjadi sebuah peraturan perundang-undangan agar mampu menyelesaiakn persoalan yang terjadi pada antara indvidu tersebut.

Pengertian aksiologi menurut Jujun S. Suriasumantri adalah teori nilai yang berkaitan dengan kegunaan dari ilmu 
pengetahuan yang diperoleh ${ }^{7}$, sedangkan Wibisono mengemukakan bahwa aksiologi adalah nilai-nilai sebagai tolak ukur kebenaran etika dan moral sebagai dasar normative penelitian dan penggalian serta penerapan ilmu. Berbicara mengenai aksilogis berarti konteksnya pada hukum perdata yang memberikan tujuan bagi masyarakat, khususnya pada individu untuk menyelesaikan permasalahan-permasalahan hukum privat. Selanjutnya mewujudkan kehidupan antara indvidu yang berjalan dengan damai, nyaman dan sejahtera.

Dalam ruang lingkup hukum perdata salah satunya mengatur mengenai keluarga (hukum kekeluargaan). Sebagaimana diketahui bahwa negara (pemerintah) telah mengatur tentang perkawinan dan hidup secara kekeluargaan, maka setiap orang perlu mengetahui hakikat keluarga itu sendiri. Dalam aspek ontologi yaitu dapat dipahaminya hakikat hubungan antara manusia dengan nilai-nilai sebuah perkawinan dan keluarga yang dilakukan antara laki-laki dan perempuan. Pada dasarnya ontologi

\footnotetext{
7 Jujun S. Suriasumantri, Filsafat Ilmu Sebuah Pengantar Populer, Pustaka Sinar Harapan, Jakarta, 1990, hlm. 60.
}

manusia yang mendasari maka hidup keluarga dan perkawinan adalah bersumber dari nilai-nilai Pancasila sebagaimana terdapat pada Pembukaan UUD RI 1945 yang menjadi landasan konstitusional Bangsa Indonesia. Maka konsep idela yang dicitacitakan berlangsung dalam keadaan serasi yang mencerminkan dapat dipenuhinya kebutuhan keluarga dan perkawinan yang berkaitan dengan pribadi (individu), sosial, dan Tuhan, sedangkan dalam aspek epistemologi yang memahami rasio manusia atas hukum keluarga dan perkawinan sehingga akan dapat dipelihara dengan baik sebagai sarana manusia untuk menunaikan kehidupannya di dunia. ${ }^{8}$ Pada aspek aksiologi berupaya mengetahui hakikat dari nilai hukum keluarga. Fokus dari nilai disini ialah mengenai baik dan buruk dari sudut pandang moral dan etika. Dimana pangkal dari keluarga yang terbentuk atas dasar perkawinan antara seorang laki-laki dan perempuan, kemudian menimbulkan hubungan keluarga. Selanjutnya dari hubungan keluarga timbul hubungan kewarisan yang

\footnotetext{
8 Samson Rahman, Islam Moderat: Menebar Islam Rahmatan Lil alamin, Pusat IKADI, Jakarta, 2007, hlm. 13.
} 
menjadi kepentingan negara untuk mengaturnya dalam hukum positif. Aspek aksiologi sebagai bagian dari filsafat sangat penting sebagai landasan ontologi manusia yang berimplikasi pada tatanan pengetahuan yang dihasilkannya.

\section{KESIMPULAN}

Berdasarkan kajian terhadap permasalahan yang telah dibahas maka kesimpulan dari penulis adalah sebagai berikut:

Hukum perdata yang merupakan aturan yang berkaitan dengan pribadi seseorang dengan orang lain Salah satu bidang hukum yang mengatur hubungan-hubungan antara individuindividu dalam masayrakat dengan sarana tertentu. Penggolongan dari hukum perdata yang ada saat ini antara lain meliputi Hukum keluarga, Hukum harta kekayaan, Hukum kebendaan, Hukum perikatan, dan Hukum waris. Dalam pemberlakuan peraturan hukum di Indonesia harus didasarkan pada falsafah Pancasila dan Undang-Undang Dasar NRI 1945. Hal yang demikian itu merupakan upaya untuk mengaktualisasikan nilai-nilai yang sudah ditanamkan oleh para pejuang
Bangsa Indonesia dalam mewujudkan kemerdekaan yang bertujuan untuk mensejahterakan seluruh bangsa Indonesia. Pemikiran yang kritis dalam mengkaji suatu persoalan (hukum) menggunakan cara filsafat dimana berkaitan langsung dengan beberapa aspek diantaranya aspek ontologi, aspek epistemologi dan aspek aksilogi. Oleh karena itu, dalam memperoleh kebenaran ilmu pengetahuan dalah hasil usaha manusia berpikir dan menyelidiki tentang pengetahuan dan keilmuan menghasilkan kebenaran nisbi, yang selalu dapat berubah dan berkembang. Begitu pula dengan kebenaran hukum yang bersumber dari ilmu sejauh mana hukum tersebut tidak bertentangan dengan Pancasila dan UUDNRI 1945, peraturan perundangundangan serta dibutuhkan dan apabila hukum tersebut bertentangan, maka menjadi tidak berlaku lagi. 


\section{DAFTAR PUSTAKA}

\section{A. Buku}

Amsal Bakhtiar, Filsafat Ilmu, Raja

Grafindo Persada, Jakarta, 2010.

Samson Rahman, Islam Moderat: Menebar Islam Rahmatan Lil alamin, Pusat IKADI, Jakarta, 2007.

Jujun S. Suriasumantri, Filsafat Ilmu Sebuah Pengantar Populer, Pustaka Sinar Harapan, Jakarta, 1990.

Tutik Titik Triwulan, Hukum Perdata dalam Sistem Hukum Nasional, Kencana, Jakarta, 2010.

\section{B. Peraturan Perundang-undangan}

Undang-Undang Dasar Negara

Republik Indonesia 1945

Kitab Undang-Undang Hukum Perdata

\section{Sumber Lainnya}

Anonim, dalam website:

https://id.scribd.com/doc/914

76706/Sejarah-Hukum-

Perdata-Indonesia

Hadi Sutoyo, Komitmen Hukum dan

Kritik Legalisme bagi Hakim,
Varia Peradilan No 293, April 2010. 